\title{
Adverbial Derivation in Toba Batak Language: A Generative Transformational Study
}

\author{
Esron Ambarita \\ Faculty of Letters \\ Universitas Methodist Indonesia \\ e-mail: esronambarita@gmail.com
}

Received: 24 September 2018

Accepted: 23 October 2018

\begin{abstract}
The purpose of this article is to elaborate adverbial derivation in Toba Batak language from the view point of generative transformational study. The data were analysed by applying modified theory with reference to Halle's model as the main theory. Therefore, there are six components of sets of generative transformational rules as modified theory in this study, i.e. List of Morphemes, Word Formation Rules, Filter, Orthographic Rules, Phonological Rules, and Dictionary. The method of this study is descriptive qualitative. The data were collected by using observation and interview. The collected data are voice-recordings and writings. The research findings show that adverbial derivation in Toba Batak language are done by attaching (1) prefix [par-], (2) prefix [maN-], (3) prefix [mar-], (4) affix combination [-umal-], and (5) affix combination [-umar-] to stems. The results of the affixation processes generate complex words which have new grammatical and lexical meanings. Phoneme assimilation takes place in morphological processes particularly with prefix [ma-]. The inflectional processes of attaching those affixes bring about phonological idiosyncrasy; therefore, such words must be processed in filter to generate acceptable words in Toba Batak language.
\end{abstract}

Keywords: adverbial, generative transformational study, derivational.

\section{Introduction}

Most studies on word formations from the view point of generative transformational study focus on nominal word formation, verbal word formation, and adjectival word formation (cf. Ambarita, 2018b, Loe, 2018; Hacken, 2017; Zainuddin, 2012; Nasution, 2011; Murdianto, 2000; Sukri, 2008; Simpen, 1995; Sudiroatmaja, 1994) and other "generative" works are still not positioned at the holistic of the compositionality scale. The aim of this study is to elaborate adverbial derivation in Toba Batak language from the view point of generative transformational study. Affixation as one of the morphological processes will generate new word when affixes are attached to stems (Ambarita, 2018c: 75).

Talking about word formation, the native speakers of a language are able to relate linguistic elements in morphological sub-systems. According to Halle (1973: 1), the speakers of a language possess knowledge not only about the words of the language but also about the composition and structure of the words. The composition and the 
structure of a word deal with the elements and forms of the word itself (Ambarita, 2016: 11).

The native speakers of a language understand original meaning of each word empirically in their own language. The change of meaning does not always alter word class because inflectional processes occur to add word characteristics (Simpen, 1995: 48). Word formation in Toba Batak language can generate acceptable words, unacceptable words, and potential words (Ambarita 2018b: 184). Unacceptable words are the implication of breaking transformation rules, and potential words are the words which are not used by speakers yet. The product of affixation and lexeme is another manifestation of word formation to form not only new different word class but also new different lexical meaning (Ambarita, 2017b: 15).

\section{Literature Review}

The theory of generative morphology proposed by Halle (1973) cannot be applied totally to analyse the data of Toba Batak language in this study. Therefore, Halle's theory is modified and adjusted to the need of this study. Two new components in modified theory are Orthographic Rules (henceforth: OR) and Phonological Rules (henceforth: PR). The data analysis, however, always refers to Halle's model as the main theory.

List of Morpheme (henceforth: LM) consists of two main types of members, i.e. stems and affixes, both inflectional and derivational affixes. The stems in LM must be labelled according to their syntactic category. Morphemes as the elements of word formation have very important roles in word formation; therefore, there are a lot of morphological issues that can be studied, not only free morphemes but also bound morphemes (Ambarita 2017c: 131). In LM all morphemes which are already identified will be grouped into two basic categories; i.e. stems and affixes. In Toba Batak language, for example, LM is realized by bases, roots, stems, and affixes such as prefixes, infixes, suffixes, and confixes (Ambarita, 2017a: 191).

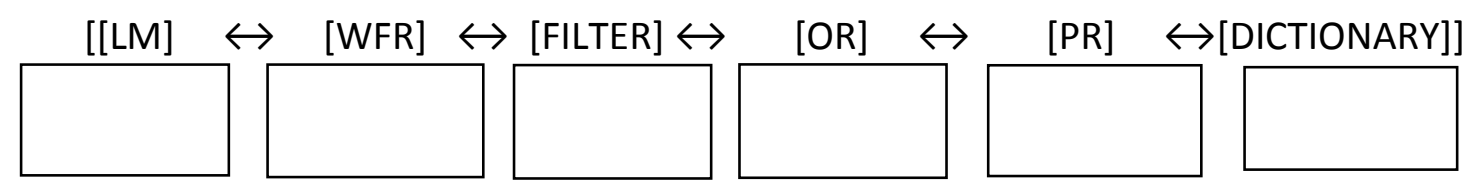

\section{Diagram of Modified Theory}

After all morphemes are listed in LM, the next step is to formulate Word Formation Rules (henceforth: WFR). WFR must be able to generate all well-formed words of a language and exclude the ill-formed ones (Ambarita, 2018a: 309). LM and WFR define the set of potential words of the language. However, not all words in a language can be formed by regular rules and common rules, but there are a lot of exceptions in a language i.e. semantic idiosyncrasies, phonological idiosyncrasies, and lexical idiosyncrasies. Scalise (1984: 16) explains the correlation of Halle's model (1973) and Aronoff's model (1976) that word formation is handled by special mechanism called WFR.

If a word is found to have such idiosyncrasies, it must be processed further in filter. On the other hand, if the word is acceptable and no idiosyncrasies are found, it will be sent to OR; OR will label orthographic rules of the word. Then, the word is sent to the next component i.e. PR; PR will detect and label it with phonological rules. Finally, PR will send the word to dictionary. The sequence of representations formed in this process is called a 
"derivation" of the phonetic representation from the underlying phonological representation (Chomsky and Halle, 1968: 60).

Derivational processes are assumed to be limited in various idiosyncratic ways (Anderson, 1982: 585). Thus, the phonological component specifies the relation between phonetic and phonological representation. According to Schane (1992: 50), when morphemes are united to form words, different segments of morphemes are in sequences and sometimes changes.

\section{Research Method}

The research was conducted in Pasar Pangururan and Tanjung Bunga, two villages located in Pangururan subdistrict, North Sumatra Province, Indonesia. The kinds of data collected in this research were voice-recordings and writings. The two kinds of data are focused on affixed-words i.e. adverbs. The voice-recording data of this research were obtained from eight informants, i.e. four informants from each of the villages. The data of this research were obtained by interviewing informants and doing documentary study. The interview was open-ended. Furthermore, the data collected from interview were recorded with an audiotape and transcribed.

This study is descriptive qualitative which describes Toba Batak language phenomena naturally. Descriptively, a language researcher describes characteristics, features, or all language phenomena which are studied through data selection (Djajasudarma, 1993: 16). The uniqueness and phenomena of a language can be known through field facts where the language is studied. Components of qualitative data analysis after data collection, according to interactive model proposed by Miles, Huberman, and Saldana (2014, 31-33), are data condensation, data display, and drawing and verifying conclusions.

The data consisting of affixes, of which the syntactic category of the lexemes are adverbs are selected to be analysed. Then, in data display, the condensed data were organized and compressed to allow conclusion drawing and verification. The findings were formulated according to the data display. Finally, conclusions were drawn based on the findings of the analysis.

\section{Results and Discussion}

Data analyses show that inflectional affixes of forming adverb (henceforth: ADV) from adverb in Toba Batak language consist of prefix (henceforth: PREF) [par-], PREF [maN-], PREF [mar-], affix combination (henceforth: AC) [-umal-], and AC [-umar]. The affixation processes of attaching those affixes generate complex words (henceforth: CW). Each of the generated words has new meanings as grammatical and lexical meanings.

\subsection{Prefix [par-]}

Morphological process in Toba Batak language to form adverb from adverb by attaching PREF [par-] is formulated as in the following steps: [STEM]ADV + [par-]PREF $\rightarrow$ [CW]ADV. More detailed illustration with example is drawn in the following modified diagram.

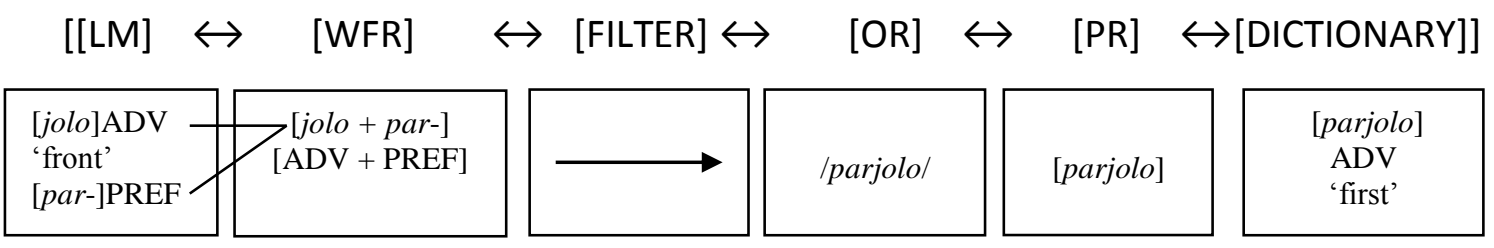


The diagram above can be explained as follows. The components found in LM are [jolo] 'front' as ADV and [par-] as PREF. These two components, later, are integrated in WFR to form CW parjolo 'first' as a new word. The filter sends the word directly to the next component i.e. OR to be given orthographic rule. The word [parjolo] as a complex neologism directly enters OR without any process in 'filter' because no idiosyncratic properties of words are found in forming the word. The next step, OR sends the word to PR to be labelled phonological rule. Finally, PR sends the ADV parjolo to dictionary to be saved as acceptable word in Toba Batak language. The rules of word formation process of the ADV parjolo can be formulated as: [STEM[jolo]ADV + PREF[par-]Noun $\rightarrow$ CW[parjolo]ADV. The process is inflectional because the result of the process does not generate new syntactic category. Grammatical meaning of [parjolo] shows 'the order as mentioned by the stem'. The lexical meaning of [parjolo] is 'first'.

\subsection{Prefix [maN-]}

Morphological process to form ADV by attaching PREF [ $\mathrm{maN}$-] is inflectional process because the process does not bring about new word class. The steps of word formation using PREF [ $\left.\mathrm{maN}^{-}\right]$are formulated as follows: [STEM]ADV $+[\mathrm{maN}-]$ PREF $\rightarrow$ [CW]ADV as shown in the following diagram.

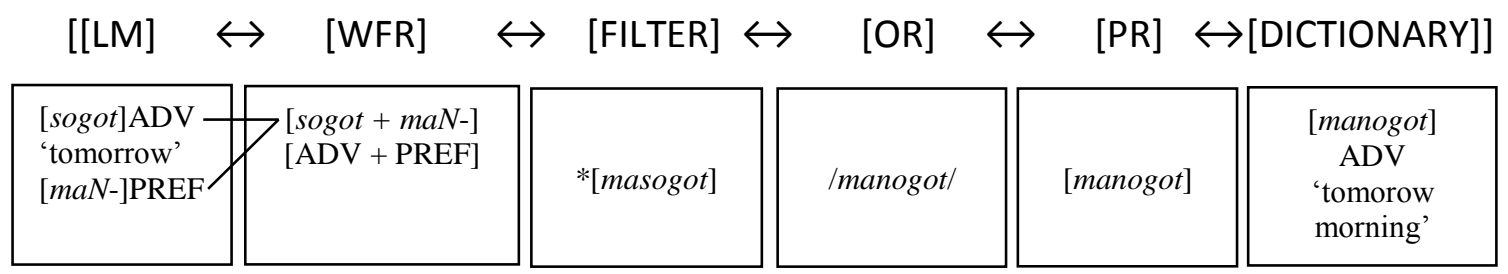

The form * [masogot] as shown in filter is unacceptable in Toba Batak language because phonological idiosyncrasy is found in forming the word. Therefore, the form must be stopped and processed in 'filter' as shown below.

$$
\begin{array}{ll}
\text { Deep Structure } & :{ }^{*}[\#[m a N-] P R E F+S T E M[\text { sogot }] \text { ADV\# }] \text { ADV } \\
& :{ }^{*}[\text { maN- }]+[\text { sogot }] \\
& :{ }^{*}[\text { masogot }] \text { (unacceptable in Toba Batak language) Phoneme }
\end{array}
$$

Assimilation: ${ }^{*}[\mathrm{maN}-]+[\mathrm{s}] \rightarrow[n]$

$$
\begin{aligned}
&:[\text { maN }-]+[\text { nogot }] \\
&:[\text { manogot] (acceptable in Toba Batak language) } \\
& \text { Surface Structure } \quad: \text { manogot [manogot] 'tomorrow morning' }
\end{aligned}
$$

Later, the acceptable form of manogot [manogot] 'tomorrow morning' is sent to OR to be given orthographic rule and continued to $P R$ to be labeled phonological rule. Furthermore, PR sends the word manogot [manogot] to dictionary to be saved as acceptable word in Toba Batak language. The process of forming the word manogot [manogot] from the stem [sogot] can be ruled out as follows: [STEM]ADV $+\quad[\mathrm{maN}-]$ PREF $\rightarrow$ [CW]ADV]. In other words, it can be said that: [STEM[sogot]ADV $\rightarrow$ [STEM[sogot $]+\operatorname{PREF}[$ maN-]Noun] + [[PHONEME ASSIMILATION[s] $\rightarrow[n]] \rightarrow$ CW[manogot]ADV].

Based on the data above, the rule of using PREF [ $\left.\mathrm{maN}^{-}\right]$can be formulated as follows: $\left[\mathrm{maN}^{-}\right] \rightarrow[$ man-] if the initial phoneme of the stem is phoneme [s]; phoneme [s] is assimilated as shown below. The process of word formation of [manogot] is inflectional because the attachment of PREF [ $\left.\mathrm{maN}^{-}\right]$to adverbial stem does not alter syntactic category. 
The grammatical meaning of [manogot] states 'part of the day as mentioned by the stem'. The lexical meaning is 'tomorrow morning'.

\subsection{Prefix [mar-]}

The grammatical function of PREF [mar-] is to form new ADV from already existing ADV. The processing steps of forming ADV using PREF [mar-] are shown in the following modified diagram.

$$
[[\mathrm{LM}] \leftrightarrow[\mathrm{WFR}] \leftrightarrow[\text { FILTER }] \leftrightarrow \quad[\mathrm{OR}] \leftrightarrow[\text { [PR } \leftrightarrow \leftrightarrow[\text { DICTIONARY] }]
$$

\begin{tabular}{|c|c|c|c|c|c|}
\hline $\begin{array}{l}\text { [sogot }] \mathrm{ADV} \\
\text { 'tomorrow' } \\
{[\text { mar-]PREF }}\end{array}$ & $\begin{array}{l}{[\text { sogot }+ \text { mar }-]} \\
{[\mathrm{ADV}+\mathrm{PREF}]}\end{array}$ & - & /marsogot/ & [marsogot $]$ & $\begin{array}{l}\text { [marsogot }] \\
\text { ADV } \\
\text { 'tomorrow' }\end{array}$ \\
\hline
\end{tabular}

The process of forming the ADV marsogot 'tomorrow' from the stem sogot 'tomorrow' is simply shown in the following scheme.

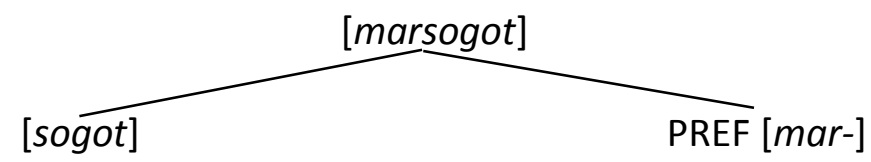

The process of forming the word marsogot can be explained as follows. The CW [marsogot] is formed from the stem [sogot] added with PREF [mar-]. In other words, the word [marsogot] consists of two morphemes, i.e. [sogot] as a free morpheme and PREF [mar-] as a bound morpheme. The process can be ruled out as: [STEM[sogot]ADV + PREF[mar-]Noun $\rightarrow$ CW[ marsogot]ADV. Grammatical meaning of [marsogot] 'states time as mentioned by the stem'. The lexical meaning of [marsogot] is 'tomorrow'. In other word, the attachment of PREF [mar-] to the stem [sogot] does not influence meaning at all.

\subsection{Affix Combination [-umal-]}

The grammatical function of AC [-umal-] is to form new ADV from ADV as shown in the diagram below.

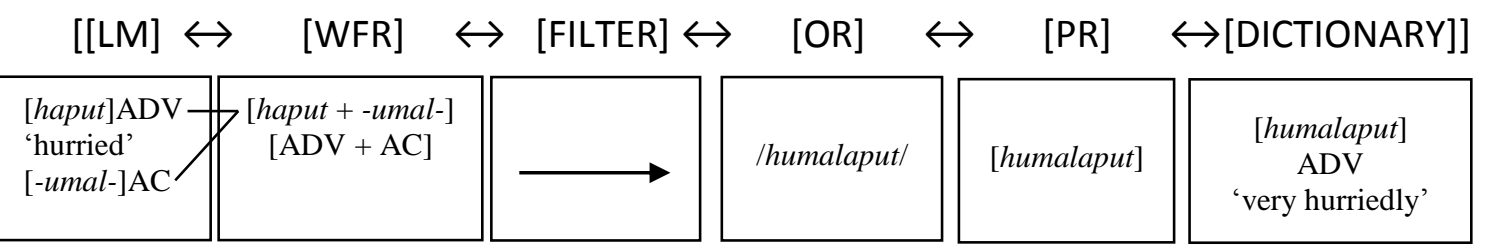

According to the diagram above, the process of forming the word humalaput is done with the following steps: The CW [humalaput] 'very hurriedly' is formed from the stem [haput] 'hurry' added with AC [-umal-]. That is to say that CW [humalaput] consists of two morphemes, i.e. [haput] as a free morpheme and CA [-umal-] as a bound morpheme. The rule of word formation of [humalaput] can be written as: [STEM[haput]ADV + AC [-umal]Noun $\rightarrow$ CW[humalaput]ADV.

In other words, ADV [humalaput] derives from the stem [haput] as a free form and AC [umal-] is inserted within the form. The grammatical meaning of [humalaput] is 'to intensify the way how to do something'. The lexical meaning of [humalaput] is 'very hurriedly'. 


\subsection{Affix Combination [-umar-]}

The steps of forming ADV using AC [-umar-] can be seen in the following diagram.

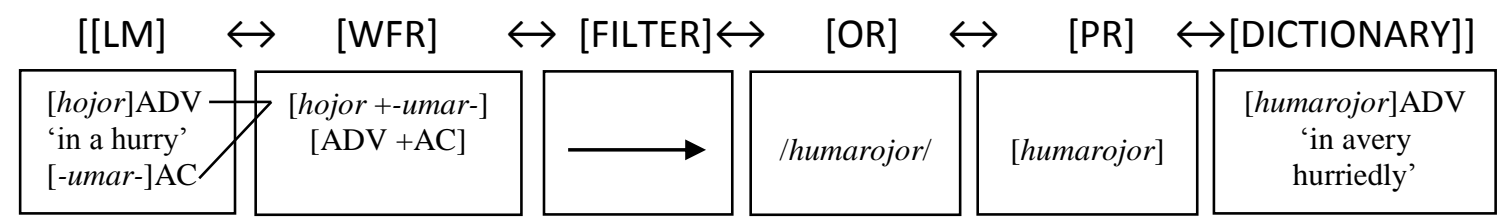

The process of combining the AC [-umar-] in the word humarojor 'in a very hurriedly' is done as shown by the following scheme:

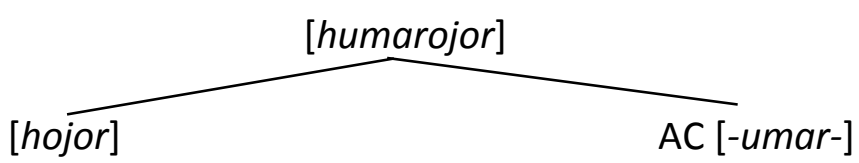

The scheme above can be explained as follows: The word [humarojor] is formed from the stem [hojor] 'in a hurry' inserted with AC [-umar-]. In other words, the CW [humarojor] consists of two morphemes, i.e. the stem [hojor] as a free morpheme and AC [-umar-] as a bound morpheme. The rule of forming $\mathrm{CW}$ [humarojor] by inserting $\mathrm{AC}$ [-umar-] can be formulated as: [STEM[hojor]ADV +AC[-umar-]Noun $\rightarrow \mathrm{CW}$ [humarojor]ADV. In other words, the ADV [humarojor] derives from the stem [hojor] as a free form inserted with AC [-umar-]. The grammatical meaning of [humarojor] is 'to intensify the way how to do something'. The lexical meaning of [humarojor] is 'in a very hurriedly'.

\section{Conclusion}

Adverbial word formation in Toba Batak language is found by attaching (1) PREF [par-], (2) PREF [maN-], (3) PREF[mar-], (4) AC [-umal-], and (5) AC [-umar-]. The results of the affixations do not generate a new word class; therefore, the processes of word formation using these affixes are inflectional. On the other hand, the neologism generates new grammatical and lexical meanings. Phonologically, idiosyncratic behaviour of words is found in some word formations. Such words must be processed in filter to generate acceptable words in Toba Batak language. In addition, phoneme assimilation occurs in the transformation of deep structure to surface structure.

This study has limitation since this study was conducted only to elaborate a generative transformational study of forming adverbs from adverbs. Therefore, other kinds of studies could be conducted such as word formation from nouns to verbs, from verbs to nouns, from adjectives to nouns, etc; it would enrich linguistic horizon to see the results of other researches on other linguistic issues.

\section{References}

Ambarita, Esron, (2018a). Deverbal Nominals in Toba Batak Language: A Generative Transformational Study. IJRR International Journal of Research and Review, Vol. 5; Issue: 9, pages 183-191; September 2018, www.ijrrjournal.com.

Ambarita, Esron, (2018b). Nominal Word Formations in Toba Batak Language: A Study of Generative Morphology. The $1^{\text {st }}$ Annual International Conference on Language and Literature (AICLL), pages 306-320, https://knepublishing.com/index.php/KneSocial/article/view/1942/4340 
Ambarita, Esron. (2018c). Adjectival Affixations in Toba Batak Language. A Descriptive Analysis of Adjectives. A Proceeding of International Conference, 5 th ELT, Linguistics, Literature, and Translation (ICELLTS), Magister of Education-English Department, Graduate School of HKBP Nommensen University, pages 74-83, https://uhn.ac.id/files/akademik_files/1806060434_2018_The\%20

Episteme\%20Journal\%20of\%20Linguistics\%20and\%20Literature\%20Vol\%204\%20No\% 203_1.\%20ADJECTIVAL\%20AFFIXATIONS\%20IN\%20TOBA\%20BATAK\%20LANGUAGE\% 20-\%20esron.pdf

Ambarita, Esron. (2017a). Daftar Morfem dalam Sistem Morfologi Generatif Bahasa Batak Toba. Jurnal TIFA, Volume 9, Nomor 1, pages 191-207, January 2017, ISSN: 20887124, Medan: Penerbit Program Pascasarjana S2 Pendidikan Bahasa Indonesia, Universitas Muslim Nusantara Al Wasliyah.

Ambarita, Esron. (2017b). Denominal Verbs in Toba Batak Language. The Episteme: Journal of Linguistics and Literature, Volume 3 Number 3, pages 13-24, May 2017, ISSN 24429392 (Print), ISSN 2460-3236 (Online), Medan: Published by English Department, Faculty of Language and Arts Nommensen HKBP University, Medan, Indonesia. https://uhn.ac.id/files/akademik_files/

1712070859_2017

The\%20Episteme\%20Journal\%20of\%20Linguistics\%20and

\%20Literature\%20Vol\%203\%20No\%203_2.Esron\%20Ambarita\%20,Denominal\%20Ver bs\%20In\%20Toba\%20Batak\%20Language.pdf

Ambarita, Esron. (2017c). Morphological Analysis of Adjective Reduplications in Toba Batak Language. Jurnal Penelitian Pendidikan Bahasa dan Sastra, Vol. 2 No. 1, pages 130137, April 2017, ISSN: 2502-9584, Medan: Penerbit Lembaga Penelitian dan Pengabdian pada Masyarakat, Universitas Muslim Nusantara Al Wasliyah, http://jurnal-Ip2m.umnaw.ac.id/index.php/ccccc/article/ download/157/149/

Ambarita, Esron. (2016). Morphological Analysis of Adjectival Affixations in Toba Batak Language. Metholangue: Language Teaching Learning, Linguistics, and Literature, Vol.

1 No. 1, pages 9-20, http://ojs.Ippmmethodistmedan. education./ index.php/METHOLANGUE/article/view/162/142

Anderson, Stephen R. (1982). Where's Morphology? Linguistic Inquiry, Volume 13 Number 4, 571-612 Winter, 4(I) I/73 (1-108) ISSN 0024-3892. URL: http://www.jstor.org/stable/4178287.

Aronoff, Mark. (1976). Word Formation in Generative Grammar. Cambridge: The MIT Press.

Chomsky, Noam dan Halle, Morris. (1968). The Sound Pattern of English. New York: Harper and Row.

Dardjowidjojo, Soenjono. (1988). Morfologi Generatif: Teori dan Permasalahan dalam PELLBA I Pertemuan Linguistik Lembaga Bahasa Atma Jaya: Pertama, Penyunting Soenjono Dardjowidjojo, Jakarta: Lembaga Bahasa Unika Atmajaya.

Djajasudarma, T.F. (1993). Metode Linguistik: Ancangan Metode Penelitian dan Kajian. Bandung: Eresco.

Hacken, Pius Ten. (2017). "Compounding in Morphology". Oxford Research Encyclopedia of Linguistics: Oxford University Press, Editor: Mark Aronoff. https://www.researchgate.net/publication/320556853 Compounding in Morpholog y

Halle, Morris. (1973). "Prolegomena to a Theory of Word Formation". Linguistic Inquiry, Volume 4 Number I, 3-16 Winter, 4(I) I/73 (1-108) ISSN 0024-3892. URL: http://www.jstor.org/stable/4177748. 
Loe, Efron Erwin Yohanis. (2018). Morfologi Bahasa Rote Dialek Dengka: Kajian Morfologi Generatif. A Dissertation, Doctoral Program of Linguistics, Faculty of Cultural Sciences, Denpasar: University of Udayana.

Miles, M. B, Huberman, A. M., \& Saldana, J. (2014). Qualitative Data Analysis: A Methods Sourcebook. 3rd Edition. Thousand Oaks: Sage Publications.

Murdianto. (2000). "Proses Pembentukan Kata Bahasa Jawa: Sebuah Kajian Transformasi Generatif". Thesis, Linguistic Program, Universitas Udayana, Denpasar.

Nasution, Khairina. (2011). Pembentukan Kata dalam Bahasa Indonesia yang Berasal dari Bahasa Arab: Kajian Morfologi Generatif. A Dissertation, Doctoral Program of Linguistics, Faculty of Cultural Sciences, Medan: University of Sumatera Utara.

Scalise, Sergio. (1984). Generative Morphology. Dordrecht-Holand/Cinnaminson-USA: Foris Publications.

Schane, Sanford A. (1973). Generative Phonology. New Jerssey: Prentice-Hall.

Simpen, I Wayan. (1995). Afiksasi Verbal Bahasa Bali: Sebuah Kajian Morfologi Generatif. A Master Thesis, Linguistic Study Program, Jakarta: University of Indonesia.

Sudiroatmaja, M.H. (1994). Morfologi Generatif: Komputasi Pembentukan Kata Bahasa Jawa in PELLBA 7 (Pertemuan Linguistik Lembaga Bahasa AtmaJaya) edited by Bambang Kaswanti Purwo. Jakarta: Lembaga Bahasa Unika Atmajaya.

Sukri, H. Muhammad. (2008). Sistem Morfologi Bahasa Sasak Dialek Kuto-Kute: Kajian Transformasi Generatif. A Dissertation, Doctoral Program of Linguistics, Faculty of Cultural Sciences, Denpasar: University of Udayana.

Zainuddin, (2012). Sistem Morfologi Bahasa Gayo: Kajian Transformasi Generatif. A Dissertation, Doctoral Program of Linguistics, Faculty of Cultural Sciences, Medan: University of Sumatera Utara. 